\title{
Efficient land use in the Russian Federation
}

\author{
Emma Shariapova ${ }^{1, *}$, Marina Matveeva ${ }^{1}$, and Andrei Shuvaev ${ }^{1}$ \\ ${ }^{1}$ Saint Petersburg State University of Architecture and Civil Engineering, 190005, St. Petersburg, 2nd \\ Krasnoarmeyskaya St., 4, Russia
}

\begin{abstract}
Efficient land use has always been the key direction of Russia's national policy. Land is the main source of wealth for any country. The idea of efficient land use has been perceived differently depending on a country and historical period. The authors of this paper assume that there are some blank spaces in modern understanding of land use efficiency in Russia. Start, development and termination of land relations are often hampered by the lack of conceptual and categorical framework, which is supposed to be the basis of the land law theory. The present study focuses on searching for weak spots in the land law of the Russian Federation and possible reasons of land misuse. The authors suggest several solutions for advancing the national policy in land matters.
\end{abstract}

\section{Introduction}

The President of the Russian Federation in the National Security Strategy calls improving the quality of life of the Russian people one of the main directions of ensuring national security. The Concept of transition of the Russian Federation to sustainable development focuses on the following: "The wealth of nature, its ability to support the development of society and capacities of self-recovery turned out to have their limits". These words prove the importance of efficient land use in the Russian Federation.

The Town Planning Code of the Russian Federation gives the definition of sustainable territory development: "sustainable development of territories means ensuring safety and favorable conditions for people's life when implementing Town Planning activities; reducing negative impact of economic and other activities on the environment and ensuring the protection and efficient use of natural resources in favor of present and future generations". On the one hand, this definition indicates the need to improve the quality of human life, and on the other hand - the need to restrain the harmful impact on the environment including land as a resource that is a product of human activity.

As the natural resource, land is not only a gift from nature, but also an important component of mankind's existence. Land is both the environment inhabited by flora and fauna of Earth, and the soil where people grow products, which are necessary to satisfy human's physical needs.

State planning of the use and protection of land resources started in Russia in the 30s of the last century. These years were marked by laying the basis for implementing measures aimed at efficient development of lands. In the fifties of the twentieth century, the USSR

\footnotetext{
* Corresponding author: sharyapova.emma@yandex.ru
} 
proceeded land development and elaborated state programs that involved the development of virgin and fallow lands. Particular attention was paid to agricultural land, as well as to the policy of protecting land from all kinds of damage. In 1968, the Fundamentals of Land Legislation of the USSR were adopted. They assigned the issues of making long-term plans for the efficient use of state lands to the jurisdiction of the Government of the USSR. These Foundations state that the specialness of agricultural land consists in meeting the demands of the Soviet people. The same legal act determines a plan of measures for land reclamation, soil fertility increasing, protecting soils from various processes that worsen their condition.

Since the seventies of the XXth century, plans for the efficient use and protection of lands have become a component of the five-year plans for the development of the national economy.

In accordance with the national policy of economic development and in order to improve the territorial development of the Russian Federation and its constituent entities and municipalities, modern Russia determines the rational use of land as one of its main directions.

\section{Materials and Methods}

Efficient land use is a concept that, first of all, implies administrative state activities, since it requires certain conditions, which are created under the guidance of state and municipal authorities. The authorities carry out measures of both organizational, administrative and legal nature, and implement certain economic measures. One of the types of the authorities' activities is the organization of the territory, and particularly territorial planning.

Territorial planning of the Russian Federation includes three levels: federal, regional and municipal. The main document of territorial planning is the Master Plan, which determines the following aspects: conditions for arranging a living space for the convenience of both people and the state, orientation for the development of both urban and rural areas, territory zoning, development of various types of infrastructure (engineering, transport, social), town planning requirements to preservation of cultural heritage sites and of specially protected natural sites and to environmental sanitary well-being. B The Master Plan provides for schemes of electricity, heat, gas and water supply facilities, public highways, bridges and other transport engineering structures, a scheme of the territory use that shows the boundaries of lands belonging to various categories, including cultural heritage sites, a scheme of boundaries of specifically used territories, a scheme of boundaries of territories exposed to risk of emergencies, the boundaries of zones that are negatively impacted by capital facilities of local significance (in case when such facilities are planned to construct), a scheme of functional zones including the program of their development, and etc. The Master Plan is a vitally important document for the population's life, since it helps create favorable conditions for territory development. The Master Plan of urban and rural settlements is adopted for at least ten years by local governments, and for cities of federal significance it is adopted by the Legislative Assemblies of the constituent entities of the Russian Federation.

The adoption of territorial planning documents such as the Master Plan, documents on urban development zoning like town planning regulations, which pertain to the Rules for Land Use and Development and are assigned to local governments by the Town Planning Code. The territorial planning of the Russian Federation and its constituent entities is assigned to the state authorities by the Constitution of the Russian Federation. The part "c" of the paragraph 1 of Art. 72 says: "The issues of ownership, use and disposal of land, 
mineral resources, water and other natural resources" are under the joint jurisdiction of the Russian Federation and the constituent entities of the Russian Federation. We believe that the functional distribution of land use among the levels of the Russian government, land use organization, planning and protection do not provide a systemic regulation of land matters, which does not help the efficient land use in the Russian Federation the sustainable development of the country. The analysis of competences of state authorities, authorities of the constituent entities of the Russian Federation and the municipal authorities gives rise to questions about the effective management of land resources in the Russian Federation.

\section{Results}

In the Russian Federation, land matters are regulated by land and town planning legislation, including the Land Code of the Russian Federation and the Town Planning Code of the Russian Federation. However, even these federal laws contain inconsistencies, which are demonstrated in the following table [1]:

Table 1. Discrepancies in Federal laws of the Russian Federation.

\begin{tabular}{|l|l|}
\hline The Land Code of the Russian Federation & $\begin{array}{l}\text { The Town Planning Code of the } \\
\text { Russian Federation }\end{array}$ \\
\hline $\begin{array}{l}\text { In the Russian Federation, lands are divided into the } \\
\text { following categories in accordance with their } \\
\text { designation purposes: }\end{array}$ & $\begin{array}{l}\text { 1. Town-development zoning specifies } \\
\text { the following zones: }\end{array}$ \\
$\begin{array}{ll}\text { 1) agricultural lands; residential zones; } \\
\text { 2) lands of settlements; }\end{array}$ \\
$\begin{array}{ll}\text { 3) lands for industry, energy, transport, and business zones, } \\
\text { communications, radio broadcasting, television, }\end{array}$ & $\begin{array}{l}\text { 3) zones of engineering and transport } \\
\text { infrastructure; }\end{array}$ \\
informatics, lands for space activities, defense, & 4) zones of agricultural use; \\
security and other special purpose lands; & 5) recreational areas; \\
4) lands of specially protected areas and objects; & 6) specially protected zones \\
5) lands of the forest reserves; & 7) special-purpose zones \\
6) lands of the water reserves; & 8) military zones and other types of \\
7) reserve lands. & zones. \\
\hline
\end{tabular}

There is the difference even in terminology. The Land Code has categories of lands, while the Town Planning Code has zones, which is apparently explained by the fact that the Land Code proceeds from soil characteristics of land, while the Town Planning Code relies on interests and needs of land developers when dividing land into functional zones.

Also, land use is regulated by such Federal laws as: Federal Law "On Land Reclamation" dated 01.10.1996 N 4-FZ, Federal Law "On Environmental Protection" dated 01.10.2002 N 7-FZ and others. These Laws and a plethora of legal acts stemming from them specify and concretize the characteristics of land as a natural resource.

\section{Discussion}

The division of land into categories indicates that it is the government that has an imperative impact on the formation and development of land relations. The state is in charge for public administration, ascribing lands and land parcels to categories, their transfer from one category to another. The Land Code of the Russian Federation prohibits the misuse of land.

The main purpose of land management is planning and organization of efficient use and protection of land. The efficient use is to be understood as the use of land by those ways 
and methods that not only meet the requirements of the legislation of the Russian Federation, but also ensure the preservation of the ecological system of Land and the ability of land to be the "producer" and the basis of human economic activity. The state is interested in getting the most out of land that belongs to it, since it is beneficial from the economic perspective. The use of land is not only the participation of land in economic turnover, but also the way people impact the land when performing their economic and other activities. Economic activity is diverse and multifaceted, it includes such works as growing crops, cultivating lands, feeding, reclamation, the use of chemicals, the work of enterprises, works on construction and operation of roads, greenspace expansion and other types of human activity. In the process of sustainable development of the Russian Federation, the efficient land use implies not only economically beneficial human activities, but also compliance with environmental requirements for the protection of land, since this natural resource is not only finite, but also needs careful attitude.

To organize the efficient use and protection of land, Russian legislation imposes the following obligations referring land matters: the obligation to preserve soils and their fertility; the obligation to protect land from water and wind erosion, mudflows, flooding, waterlogging, secondary salinization, desiccation, compaction, radioactive chemical contamination, littering with industrial waste, and relieving the consequences of pollution; the obligation to protect agricultural land from overgrowing with trees and shrubs, weeds; the obligation to maintain the achieved level of reclamation; obligation to cultivate disturbed lands; obligation to restore soil fertility; obligation to timely involve land into turnover. These responsibilities relate to owners of land parcels, land users, landowners and farmers renting land parcels. The procedure for land reclamation and conservation is regulated by the Decree of the Government of the Russian Federation of July 10, 2018 No. 800 "On Land Reclamation and Conservation." The rules contained in the Decree define the grounds for land reclamation and conservation, the group of persons under the purview of whom is to take the measures, the procedure of taking these measures for land reclamation and conservation, as well as the methods that help achieve efficient land use.

Land survey methods play an important role when making land use more efficient. These methods are the basis for compiling a soil map of the land, which reflects the quality of soils. Russian legislation in the Federal Law "On Land Management" of 18.06.2001 N 78-FZ names various methods of surveying land. The whole article No. 11 is devoted to types of surveys: soil survey, geobotanical survey and other types. According to the legislation, soil survey includes:

- soil zoning, i.e. division of the territory depending on topsoil;

- soil reclamation zoning, i.e. division of the territory based on natural and irrigationand-economic characteristics;

- compilation of a soil-erosion map, which displays the distribution of soil by the degree of erosion;

- execution of soil surveys;

- compilation of a rating map, i.e. graphic representation of appraisal by points of soils in a territory.

It is known that while life on earth has been developing, soils, especially in the context of global climate changes, lose their properties, change, and sometimes in negatively. Therefore, in order to obtain the required accuracy in soil surveys, the materials must be updated every twenty-five years.

Geobotanical surveys relate to the study of vegetation cover within the boundaries of a certain territory or land parcel and include such indicators as plant climate, metabolism and other indicators of soil that are inseparable from biocenosis and biogeocenosis. Other surveys and inspections involve methods that may be topographic and geodetic, geological 
and geomorphological, agrochemical, sanitary and epidemiological. The sanitaryepidemiological method is important for determining the quality of soils, settlements and agricultural lands. It determines the observance of hygienic standards during the construction, reconstruction and operation of objects designed for various purposes, which may negatively impact the condition of soil. This method allows making a sanitary and epidemiological assessment of the condition of soil, which help detect a potential source of soil pollution. This assessment should be taken into account when choosing a site for construction, which is possible during engineering surveys that show not only the affordability of construction, but also the environmental forecast for a given land parcel. Sanitary and epidemiological research to perform at the sites of industrial enterprises, gas stations and landfills is also relevant.

Geological and morphological surveys enable studying the relief of the earth's surface in terms of the impact of human economic activity on the state and changes of soil, as well as on the state of environmental quality.

The hygienic assessment of soil, for example, of that purposed for agricultural activities, provides the following information: the chemical composition of products used in agriculture, the rational choice of places for storages for mineral fertilizers, the location of waste from livestock breeding complexes, the characteristics of sanitary state of soil, methods of land irrigation, as well as soil properties that can affect the state of a greenery system.

All of the above methods of surveys and inspections determine the estimation of the quality of land; therefore, it is important to execute all researches in special laboratories accredited in the manner prescribed by law.

Efficient land use also includes an economic component, so is worth to pay attention to such an indicator of land quality as its productivity. The main criterion for land productivity is its fertility, which this applies primarily to agricultural land. It is fertility (i.e. the ability of soil to satisfy the need of agricultural plants in such elements as nutrients, air, water, heat, physicochemical and biological environment) that is able to provide a high agricultural output of crops. A high rate of agricultural output is one of the indicators of the life quality that underlies the national policy of the Russian Federation. There is such a term as land quality assessment. Despite the fact that the legislation does not have a procedure for assessment of the quality of land and it is possible only in by-laws, nevertheless, there are principles of this process that are possible to derive. They consist in the following: the assessment must be scientifically grounded, carried out using proven means and methods, must correspond to the modern development level of science and technology, must be carried out by professional specialists who besides a degree in the relevant area have work experience; the assessment must be carried out within an appropriate time frame, should be documented and contain a description of the characteristics of a land as a source of production.

There are various methods of land assessment, which we consider according to the classification of the theoretician lawyer O.L. Dubovik. Each of these methods is applied when the land use is reasonable. For instance, in terms of economics, the following methods are used: the sales comparison method, the land rent capitalization method, the remainder method, the intended use method. For construction purposes, the allocation method and the distribution method are used, which allow identifying the level of developed land parcels as well as undeveloped ones for further possible use of those parcels for construction.

It is observable that methods of surveying soil are associated not only with the difficulty of the processes being performed, but also with the need for specialists, personnel and scientists who could carry out these activities aimed at the assessment of land's quality. 
These processes require whole laboratories and research institutes, which represent government agencies that, at the request of the state, plan, organize and carry out soil studies of the lands of the Russian Federation. There is formed a triangle of subjects, which are responsible for monitoring the state of land quality. The question is which of these subjects take responsibility for replenishing the qualities and properties of land cover on the territory of the Russian Federation. There is an opinion that the current map of functional zones of municipalities does not allow rehabilitating anything concerning the land purpose [2]. Legislators save the possibility of transferring land from one category to another. The competence of local governments in regulating issues of town planning is great, yet sometimes it comes into conflict with plans for territorial development of a constituent entity and of the Russian Federation, since functional zones are defined by local authorities, and land categories are determined by state authorities at the federal level.

Land protection involves not only the elaboration of methods and ways to increase the benefits of land use, especially its fertility, but also the legal regulation of liability for violation of legal land relations. Addressing to the practice of litigation, we can conclude that lawsuits are mainly lodged for the misuse of land parcels, which is a small share of possible sets of offenses on land matters.

\section{Conclusions}

Efficient land use is one of the key components of sustainable development of the Russian Federation. Land and its resources are the national treasures of the country. Besides being protected, these treasures should also be multiplied, since the well-being of people depends on the productivity of land use.

For the further effective development of ways and methods for the efficient land use, the authors of the present paper suggest paying attention to the following aspects:

- the most resourceful lands of the Russian Federation are, first of all, agricultural lands; therefore, it seems important and even necessary to assign a special status to the category of agricultural lands, like it has been assigned to lands of the Far North;

- the distribution of competences in land matters between state and municipal authorities does not always benefit the efficient land use, which leads to non-systemic studies, as whey are administered by different levels of government;

- Responsibility prescribed in Russian legislation does not correspond to the level of damage that is caused by misuse of land, negative impact on land of human economic activities, improper organization and zoning of the territory of the Russian Federation, improper territorial development, elaboration of shortsighted, incomplete, defective legal acts that reveal the lack of knowledge among the officials who are in charge of this area.

The modern efficient land use and protection should involve technologies corresponding to the current development level of science and technology, particularly software engineering, automation and modernization.

\section{References}

1. V. V. Polyakov, N. B. Sukhomlinova. Instrumental-structural mechanism of the solution of land use problems in new conditions of managing, Economy and ecology of territorial formations 2(1), 22-23 (2018) 
2. A. S. Cheshev. Organizational and economic aspects of a systematic approach to land management in modern conditions, Economy and ecology of territorial formations 2(2), 13-23 (2018) DOI: 10.23947/2413-14742-2-13-23 